\title{
Microbial growth in biobeds for treatment of residual pesticide in banana plantations
}

\author{
Verónica I Domínguez-Rodríguez ${ }^{1}$, Eduardo Baltierra-Trejo ${ }^{\text {Corresp., } 1,2}{ }$, Rodolfo Gómez-Cruz ${ }^{1}$, Randy H Adams ${ }^{1}$ \\ ${ }^{1}$ División Académica de Ciencias Biológicas, Universidad Juárez Autónoma de Tabasco, Villahermosa, Tabasco, Mexico \\ 2 Catédras CONACyT, Consejo Nacional de Ciencia y Tecnología, Mexico City, Mexico \\ Corresponding Author: Eduardo Baltierra-Trejo \\ Email address: eduardo.baltierra@conacyt.mx
}

Background. High doses of ethylenebisdithiocarbamate (EBDC) are used in banana production, and unused pesticide mixture (solution) is often disposed of improperly. This can result in soil and water contamination and present an undue risk to rural communities and the environment. An alternative to reduce the environmental impacts caused by pesticide residues is the biobeds treatment. It is necessary to establish if the composition of the proposed biomixtures supports microbial activity to degrade pesticides in biobeds. This research aimed to evaluate the EBDC effect on the distribution and abundance of microbial populations in polluted biomixtures .

Methods. For this purpose, a biomixture based on banana stem, mulch, and Fluvisol soil (50:25:25 \% $\mathrm{v} / \mathrm{v}$ ) was prepared and polluted with $1000 \mathrm{mg} \mathrm{L}^{-1} \mathrm{EBDC}$. The response variables kinetics were determined every 14 days for three months, such as $\mathrm{pH}$, organic matter, moisture, cation exchange capacity, microbial colonies, and cell counts at three depths within the experimental units.

Results. EBDC reduced the number of microbial colonies by $72 \%$. Bacterial cells rapidly decreased by $69 \%$ and fungi $89 \%$ on the surface, while the decrease was gradual and steady at the middle and bottom of the biobed. The microbial populations stabilized at day 42 , and the bacteria showed a total recovery on day 84 , but the fungi slightly less. At the end of the experiment, the concentration of EBDC in the biomixture was 1.3-4.1 mg L $\mathrm{L}^{-1}$. A correlation was found between fungal count (colonies and cells) with EBDC concentration. A replacement of the biomixture is suggested if the bacterial population becomes

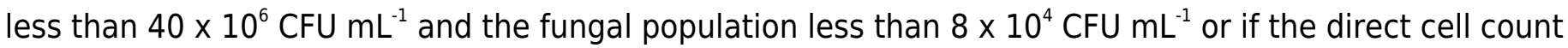
becomes lower than $50 \times 10^{4}$ cells $\mathrm{mL}^{-1}$ in bacteria and $8 \times 10^{2}$ cells $\mathrm{mL}^{-1}$ in fungi.

Conclusion. The biomixture based on banana stem supports the microbial activity necessary for the degradation of the EBDC pesticide. It was found that fungi could be used as indicators of the pollutant degradation process in the biomixtures. Microbial counts were useful to establish the mobility and degradation time of the pesticide and the effectiveness of the biomixture. Based on the results, it is appropriate to include the quantification of microbial populations to assess the effectiveness of pesticide degradation and the maturity level of the biomixture. 
1 Microbial growth in biobeds for treatment of residual

2 pesticide in banana plantations

3

4

5

6

7

8

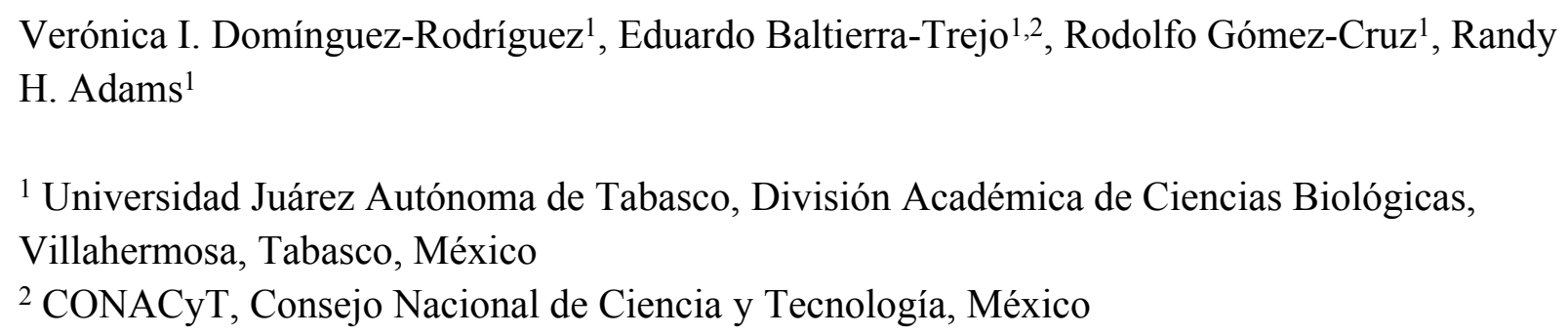

\section{Abstract}

Background. High doses of ethylenebisdithiocarbamate (EBDC) are used in banana production, and unused pesticide mixture (solution) is often disposed of improperly. This can result in soil and water contamination and present an undue risk to rural communities and the environment. An alternative to reduce the environmental impacts caused by pesticide residues is the biobeds treatment. It is necessary to establish if the composition of the proposed biomixtures supports microbial activity to degrade pesticides in biobeds. This research aimed to evaluate the EBDC effect on the distribution and abundance of microbial populations in polluted biomixtures. Methods. For this purpose, a biomixture based on banana stem, mulch, and Fluvisol soil $(50: 25: 25 \% \mathrm{v} / \mathrm{v})$ was prepared and polluted with $1000 \mathrm{mg} \mathrm{L}^{-1} \mathrm{EBDC}$. The response variables kinetics were determined every 14 days for three months, such as $\mathrm{pH}$, organic matter, moisture, cation exchange capacity, microbial colonies, and cell counts at three depths within the experimental units.

Results. EBDC reduced the number of microbial colonies by $72 \%$. Bacterial cells rapidly decreased by $69 \%$ and fungi $89 \%$ on the surface, while the decrease was gradual and steady at the middle and bottom of the biobed. The microbial populations stabilized at day 42 , and the bacteria showed a total recovery on day 84 , but the fungi slightly less. At the end of the experiment, the concentration of EBDC in the biomixture was $1.6-5.3 \mathrm{mg} \mathrm{kg}^{-1}$. A correlation was found between fungal count (colonies and cells) with EBDC concentration. A replacement of the biomixture is suggested if the bacterial population becomes less than $40 \times 10^{6} \mathrm{CFU} \mathrm{mL}^{-1}$ and the fungal population less than $80 \times 10^{3} \mathrm{CFU} \mathrm{mL}^{-1}$ or if the direct cell count becomes lower than 50 x $10^{4}$ cells $\mathrm{mL}^{-1}$ in bacteria and $80 \times 10^{1}$ cells $\mathrm{mL}^{-1}$ in fungi. 
Conclusion. The biomixture based on banana stem supports the microbial activity necessary for the degradation of the EBDC pesticide. It was found that fungi could be used as indicators of the pollutant degradation process in the biomixtures. Microbial counts were useful to establish the mobility and degradation time of the pesticide and the effectiveness of the biomixture. Based on the results, it is appropriate to include the quantification of microbial populations to assess the effectiveness of pesticide degradation and the maturity level of the biomixture.

\section{Introduction}

It is estimated that 155 million tons of bananas are produced annually in tropical regions of the world (FAO 2019). Humid conditions and high temperatures favor the appearance of pests. The most frequent and damaging is the black Sigatoka fungus. (Mycosphaerella fijiensis Morelet) (Drenth \& Guest 2016). The fungicide ethylenebisdithiocarbamate (EBDC), commercially known as Mancozeb, is applied at weekly doses of $2 \mathrm{~kg} \mathrm{ha}^{-1}$ throughout the year to maintain intensive production. EBDC has a short half-life in the environment, but it degrades by photooxidation into ethylenethiourea (ETU), a recalcitrant compound with mutagenic and carcinogenic potential (Gupta 2018).

ETU is mobilized in the environment due to spills and inappropriate practices during the filling application equipment, thus contaminating soil and water (Morillo \& Villaverde 2017). It has been found that the concentration of ETU in wastewater generated in banana plantations is as high as $800 \mathrm{mg} \mathrm{L}^{-1}$ (Domínguez et al. 2015; Geissen et al. 2010). As a result, workers and inhabitants in banana plantations may be exposed to acute poisoning and chronic degenerative diseases (Rea \& Patel 2017). It is estimated that three million acute pesticide poisoning cases occur each year worldwide in agricultural areas, of which $10 \%$ are fatal (Mew et al. 2017). Therefore, it is necessary to develop strategies to mitigate the impact of pesticides. An alternative for treating pesticide residues is to adsorb and degrade them in a construction known as biobed. According to the original model proposed in Sweden, the biobed is filled with organic substrates or biomixture, composed of soil, peat from swamps, and wheat straw (Torstensson 2000). In the Swedish biomixture, peat from swamps is the primary source of microorganisms, while wheat straw is a source of carbon and lignin, stimulating fungi enzymatic activity (Castillo \& Torstensson 2007). The useful life of the Swedish biomixture has been estimated at 6-8 years (Torstensson 2000).

Peat and wheat straw are difficult to obtain near banana-producing areas, but locally available materials could be used in biomixtures production (Vischetti et al. 2007). In this respect, alternatives have been investigated to replace peat with another material with pollutant sorption capacity. For example, Vischetti et al. (2007) evaluated the use of biomixtures prepared with composts, Gao et al. (2015) spent mushroom substrate, and Mukherjee et al. (2016) with biochar. Other researches have evaluated the use of alternative sources of lignin to replace straw. For example, Karanasios et al. (2010) found promising results in corn cobs, sunflower residues, grape stalks, orange peels, olive tree pruning, and citrus peel; while Domínguez et al. (2021) used sugarcane tip, eucalyptus chip, and banana stem. 
79 Therefore, it is necessary to evaluate the degradability and useful life of the proposed

80 biomixtures. (Dzionek et al. 2016). Among the parameters proposed for monitoring the

81 biomixtures are the moisture, $\mathrm{pH}$, cation exchange capacity, organic matter, carbon, and nitrogen

82 content (Delgado et al. 2019; Karanasios et al. 2010); and biological variables such as enzyme

83 activity, respiration, and microbial biomass (Adak et al. 2020; Vischetti et al. 2007). In this

84 regard, the biological factors involved have been less addressed.

85 For example, Vischetti et al. (2007) compared the degradation of the chlorpyrifos pesticide at a

86 concentration of $50 \mathrm{mg} \mathrm{kg}^{-1}$ in a biobed with two different biomixtures, one with peat and the

87 other with compost mixed with vine pruning and soil. The biomixtures with peat showed a

88 higher pesticide degradation than the compost. Furthermore, in the biomixtures, the pesticide

89 inhibited the respiratory activity by $50 \%$ and the microbial biomass by $60 \%$, while with peat,

90 there was no inhibition. The biomixture with peat had a higher abundance of microbial species,

91 mainly fungi. They concluded that fungal diversity was related to the $\mathrm{pH}$ and higher carbon

92 content.

93 Subsequent studies have considered the influence of environmental factors on microbial activity

94 during the degradation of pesticides in the biomixtures. For example, Castro et al. (2017)

95 evaluated the effect of carbofuran $\left(20 \mathrm{mg} \mathrm{kg}^{-1}\right)$ on microbial species diversity in a biomixture at

$9625^{\circ} \mathrm{C}$. It was determined that the biomixture gradually lost its effectiveness, and only $88 \%$ of

97 the pesticide was degraded in 180 days. It was concluded that species diversity varied mainly due

98 to the biomixture aging and secondarily due to the pesticide. The useful life of the biomixture at

$9925^{\circ} \mathrm{C}$ was considered to be one year.

100 On the other hand, Adak et al. (2020) evaluated the effect on microorganisms of imidacloprid

$101\left(178 \mathrm{mg} \mathrm{kg}^{-1}\right)$ in a biomixture prepared with straw, manure, and soil $(2: 1: 1 \mathrm{v})$ in a tropical

102 climate. After 90 days, $95 \%$ of degradation was achieved. The pesticide degradation was related

103 to fluorescein diacetate hydrolase and dehydrogenase enzyme activities, but not to $\beta$-glucosidase.

104 It was concluded that fungi were less affected than bacteria by the pesticide.

105 Therefore, research evaluating the relationship of physicochemical and biological parameters in

106 different biomixtures, and climates is of interest. The microbiological studies would identify the

107 effectiveness or depletion of the biomixture, the accumulation or mineralization of toxic

108 compounds, and the mobility of pesticides in the biobed (Vareli et al. 2018). In this sense,

109 previous research has not considered microbial colony and cell counts. The research aim of the

110 present study was to evaluate the effect of EBDC on the distribution and growth of fungi and

111 bacteria in a biomixture prepared with materials available in a banana plantation under warm-

112 humid conditions. Therefore, a biomixture based on banana stem, soil, and mulch was prepared

113 and polluted with 1,000 $\mathrm{mg} \mathrm{L}^{-1}$ EBDC. Subsequently, the degradation into ETU was evaluated as

114 well as the effect on microbial colonies and cells at three depths within the experimental units.

115

\section{Materials \& Methods}

117 The toxic effect of the EBDC on microbial distribution and abundance in simulated biobeds was

118 evaluated in a tropical-humid environment. The biomixture used was based on banana stem, 
119 mulch, and soil. The degradation kinetics of the pesticide was performed for three months, as 120 described below:

121

122

123

124

125

126

127

128

129

130

131

132

133

134

135

136

137

138

139

140

141

142

143

144

145

146

147

148

149

150

151

152

153

154

155

156

157

158

Preparation of the biomixture and experimental units. The materials required for biomixture, such as banana stem, mulch (top "O" layer of soil formed mainly by decomposing leaf litter in the banana plantation), and soil (Fluvisol) from a depth of 25 to $50 \mathrm{~cm}$, were collected at Ranchería Miahuatlán, Tabasco (longitude: 18.020500, latitude: -93.297000). The banana stem was chopped into fragments of approximately $3 \times 1 \mathrm{~cm}$. Banana stem, mulch, and soil were mixed in the ratio of 50:25:25\% (v/v). The biomixture was composted for 50 days before the pollution. The physicochemical characterization of the soil and the materials used in the preparation of the biomixture was carried out. The results are shown in Table 1.

Biobeds were simulated in laboratory-scale experimental units built with polyethylene cylinders (length $50 \mathrm{~cm}$, diameter $9.5 \mathrm{~cm}$ ). The experimental units were buried at ground level to simulate field conditions and kept in an outdoor patio adjacent to the laboratory. During the study period, the ambient temperature was approximately $20-35^{\circ} \mathrm{C}$. The arrangement of the units was randomized. Manual irrigation was performed twice a week, with $300 \mathrm{~mL}$ of water per unit, evenly spreading the liquid on the surface of the biobeds.

Four treatments were evaluated: unpolluted and polluted biomixtures, unpolluted and polluted soils. Polluted treatments were irrigated at the beginning of the experiment with $1000 \mathrm{mg} \mathrm{L}^{-1}$ EBDC (Mancozeb $\left.{ }^{\circledR}\right)$.

Openings of $5 \mathrm{~cm}$ in diameter were made to sample the experimental units at three depth levels: surface $(5-10 \mathrm{~cm})$, middle $(25-30 \mathrm{~cm})$, and bottom $(45-50 \mathrm{~cm})$. The samples were taken from the units with a spoon twice a week for 84 days to evaluate physicochemical parameters: field capacity, $\mathrm{pH}$, humidity, cation exchange capacity, organic matter content, and pesticide concentration, as well as biological parameters: number of microbial colonies and cell count in suspension. The samples of each variable were compared at three levels of depth throughout the experimental unit.

Soil texture. The hydrometer or Bouyoucos method was used to determine the soil texture. $30 \%$ $\mathrm{H}_{2} \mathrm{O}_{2}$ was added to $60 \mathrm{~g}$ of a soil sample to oxidize the organic matter. Water and $10 \mathrm{~mL}$ of sodium hexametaphosphate $\left(\mathrm{NaPO}_{3}\right)_{6}$ were added to $50 \mathrm{~g}$ of disaggregated sample. The components were mixed for 5 minutes. The mixture was topped-off at 1,000 mL with distilled water, stirred for 1 minute, and analyzed at 40 seconds and 2 hours with the hydrometer and thermometer (Pansu \& Gautheyrou 2007).

Field capacity (FC). $100 \mathrm{~g}$ of dry sample was moistened with water. Afterwards, the wet sample was drained for $24 \mathrm{~h}$ and weighed. It was then dried at $60^{\circ} \mathrm{C}$ for $24 \mathrm{~h}$ (Kirkham, 2014; Pansu \& Gautheyrou, 2007). The field capacity was calculated with Equation 1:

$\% \mathrm{FC}=\frac{\text { wet weight }(\mathrm{g})-\text { dry weight }(\mathrm{g})}{\text { wet weight }(\mathrm{g})} \times 100$

Equation 1 
159

160

161

162

163

164

165

166

167

168

169

170

171

172

173

174

175

176

177

178

179

180

181

182

183

184

185

186

187

188

189

190

191

192

193

194

195

196

197

198

199

200

Total organic carbon. This was determined in the materials used to prepare the biomixtures, using the Walkley-Black method (De Vos et al. 2007). To $0.5 \mathrm{~g}$ of soil was added $5 \mathrm{~mL}$ of $\mathrm{K}_{2} \mathrm{Cr}_{2} \mathrm{O}_{7}$ and $10 \mathrm{~mL}$ of $\mathrm{H}_{2} \mathrm{SO}_{4}$. The mixture was let digests for $30 \mathrm{~min}$, and $5 \mathrm{~mL}$ of $\mathrm{H}_{3} \mathrm{PO}_{4}$ and $100 \mathrm{~mL}$ of water were added. Finally, it was titrated with $\mathrm{FeSO}_{4}$ and diphenylamine indicator.

Total nitrogen. This was determined in the materials used to prepare the biomixture by the Nessler method (Yuen \& Pollard 1954). One gram of sample was dissolved in $20 \mathrm{~mL}$ of water, centrifuged at 2,000 rpm for 10 minutes, and filtered with Whatman paper \# 42. To $20 \mathrm{~mL}$ of filtrate, three drops of polyvinyl alcohol and $1 \mathrm{~mL}$ of Nessler reagent were added. The absorbance was measured at $440 \mathrm{~nm}$ in a spectrophotometer (Thermo scientific Genesys 10S UV-VIS).

$p H$. To $10 \mathrm{~g}$ of sample, $50 \mathrm{~mL}$ of distilled water were added. The suspension was stirred (30 minutes, at $80 \mathrm{rpm}$ ) and left to stand for 10 minutes. The $\mathrm{pH}$ was measured with the potentiometer (Hanna HI98195) (Pansu \& Gautheyrou 2007).

Moisture. This was determined by gravimetry. $5 \mathrm{~g}$ of sample (previously dried at $110{ }^{\circ} \mathrm{C}$ for 2 hours) was placed in a desiccator. Its weight was measured on an analytical balance until a constant weight was obtained (Pansu \& Gautheyrou 2007).

Cation Exchange Capacity (CEC). $5 \mathrm{~g}$ of soil was placed in a funnel with filter paper. $10 \mathrm{~mL}$ of $1 \mathrm{~N} \mathrm{CaCl}_{2}$ was added to the sample and repeated five times. Then, $10 \mathrm{~mL}$ of ethanol was added five times, and the filtrate was removed. $5 \mathrm{~mL}$ of $1 \mathrm{~N} \mathrm{NaCl}$ was added five times, the filtrate (liquid) was stored and topped-off at $50 \mathrm{~mL}$ with $1 \mathrm{~N} \mathrm{NaCl}$. Subsequently, $10 \mathrm{~mL}$ of the buffer solution $\mathrm{pH} 10\left(67.5 \mathrm{~mL}\right.$ of $\mathrm{NH}_{4} \mathrm{Cl}$ and $570 \mathrm{~mL}$ of $\mathrm{NH}_{4} \mathrm{OH}$ topped-off at $1000 \mathrm{~mL}$ with water) was added. Five drops of $\mathrm{KCN} 2 \%$ solution and five drops of eriochrome black T indicator solution $\left(0.1 \mathrm{~g}\right.$ indicator and $1 \mathrm{~g} \mathrm{NH}_{2} \mathrm{OH} \mathrm{HCl}$ [hydroxylamine hydrochloride], diluted in $25 \mathrm{~mL}$ of methanol) were added. Finally, it was titrated with $0.05 \mathrm{~N}$ EDTA (versanate). The endpoint changed color from purple to blue (Garman \& Hesse 1975; Pansu \& Gautheyrou 2007). The CEC was calculated with Equation 2:

$\operatorname{CEC}\left(\mathrm{cmol}(+) \mathrm{kg}^{-1}\right)=\frac{\text { volume EDTA }(\mathrm{mL}) \times \operatorname{EDTAN}(\mathrm{eq} \mathrm{g} \mathrm{L}-1) \times \mathrm{CF}}{\text { sample weight }(\mathrm{g})}$ Equation 2

where $\mathrm{CF}$ is the correction factor $=(10 \mathrm{~mL} \times 0.02 \mathrm{~N}) / \mathrm{mL}$ EDTA $($ EDTA spend $(\mathrm{mL})$ in the titration of 10 $\mathrm{mL} \mathrm{CaCl}_{2} 0.02 \mathrm{~N}$ solution). The CEC was expressed in the International System of units as $\mathrm{cmol}^{(+)} \mathrm{kg}^{-1}$.

Organic matter content. This was determined by gravimetry using the loss-on-ignition method. 5 $\mathrm{g}$ of the sample was heated to $400^{\circ} \mathrm{C}$ in an oven for 1 hour. It was then placed in a desiccator and weighed on an analytical balance until a constant weight was obtained.

Concentration of ETU. To $2 \mathrm{~g}$ of soil or biomixture (previously dried), $5 \mathrm{~mL}$ of methanol-water solution (1:1) was added, vortex stirred for 2 minutes at $100 \mathrm{rpm}$, warmed at $70^{\circ} \mathrm{C}$ (in a water

Peer] reviewing PDF | (2021:02:57885:2:0:NEW 12 Aug 2021) 
201

202

203

204

205

206

207

208

209

210

211

212

213

214

215

216

217

218

219

220

221

222

223

224

225

226

227

228

229

230

231

232

233

234

235

236

237

238

239

bath) for 8 minutes and, treated in an ultrasonic bath for 15 minutes (Branson 2800). The sample was filtered under vacuum using a Büchner funnel and Whatman \# 41 filter paper and centrifuged at 3,000 rpm for 15 minutes. The supernatant was filtered under vacuum using a 2 $\mu \mathrm{m}$ filter (Millipore). The sample was measured at $232 \mathrm{~nm}$ with a spectrophotometer (Thermo scientific Genesys 10S UV-VIS) (Domínguez et al. 2021).

Microbial cultures. For the isolation of bacteria and fungi, the plate dilution technique was used.

The procedure was performed under aseptic conditions; $5 \mathrm{~g}$ of soil was weighed and placed in 45 $\mathrm{mL}$ of sterile water, and vortex stirred for 30 seconds. An aliquot of $1 \mathrm{~mL}$ was taken to prepare dilutions from $10^{-1}$ to $10^{-5}$. From each dilution, $100 \mu \mathrm{L}$ were taken to inoculate Petri dishes with culture medium, in which the number of colonies was then evaluated. Bacteria were cultured for 24 hours at $30^{\circ} \mathrm{C}$ on $23 \mathrm{~g} \mathrm{~L}^{-1}$ nutrient agar (MCD Lab) with $500 \mathrm{~mL} \mathrm{~L}^{-1}$ soil extract, and $\mathrm{pH}$ adjusted to 5.6. The fungi were cultured for five days at $30^{\circ} \mathrm{C}$ on $30 \mathrm{~g} \mathrm{~L}^{-1} \mathrm{Sabouraud}$ agar culture medium (MCD Lab) with a mixture of $500 \mathrm{~mL} \mathrm{~L}^{-1}$ soil extract and $500 \mathrm{mg} \mathrm{L}^{-1}$ chloramphenicol. The soil extract was prepared with a $1 \mathrm{~kg} \mathrm{~L}^{-1}$ solution of Fluvisol soil, which was sterilized in an autoclave at $15 \mathrm{PSI}, 121^{\circ} \mathrm{C}$ for 15 minutes, filtered under vacuum (Whatman \#42 filter paper), and the supernatant was topped-off at $1,000 \mathrm{~mL}$ with distilled water (Atlas 2005; Mueller et al. 2011).

Colony count. The colony-forming units (CFU) were calculated through an analog colony counter with a magnifying glass. The CFU's of each treatment were calculated with Equation 3:

$\mathrm{CFU} \mathrm{mL} \mathrm{mL}^{-1}=\frac{\text { Colonies counted } \mathrm{x} \text { reciprocal of the dilution }}{\text { Added volume }(0.1 \mathrm{~mL})} \quad$ Equation 3

Microbial cell count. The procedure was repeated for each of the dilutions of soil samples previously prepared. A $10 \mu \mathrm{L}$ drop of the corresponding dilution was placed in the Neubauer chamber. The number of bacterial cells and the number of fungal cells were observed by the optical microscope at magnifications of $100 \mathrm{X}$ and $40 \mathrm{X}$, respectively. The number of microbial cells was calculated with Equation 4:
cells $\mathrm{mL}^{-1}=\frac{\text { cell count } \times \text { reciprocal of the dilution }}{\text { area }\left(0.2 \mathrm{~mm}^{2}\right) \times \text { chamber depth }(0.1 \mathrm{~mm})}$
Equation 4

Experimental design and analysis of results. The effect of EBDC on biomixture was analyzed. Unpolluted biomixture, polluted soil, and unpolluted soil were used as controls with three replicates per treatment. The experimental design was completely randomized. Response variables were evaluated and plotted over a 3-month kinetic with measurements every 14 days. Differences between treatments were analyzed using ANOVA and the Tukey-Kramer HSD test (honestly significant difference) with a significance level $\alpha=0.05$. Spearman's multivariate statistical analysis was performed to describe the relationships between the variables studied. 
240 The statistical analysis was performed using the JMP 11.0.0 statistical software (Statistical

241 Analysis System SAS $\left.{ }^{\circledR}, 2014\right)$.

242

243 Results

\section{Kinetics of physicochemical parameters}

245 The physicochemical variables were evaluated in the experimental units with soil and biomixture 246 for 84 days. The variables considered were $\mathrm{pH}$, moisture, CEC, organic matter content, and ETU 247 concentration.

248 The $\mathrm{pH}$ tended to increase from slightly acidic to alkaline in all treatments. The $\mathrm{pH}$ varied from 2495.9 to 7.9 in the polluted biomixture throughout the experiment. Slightly lower than in the 250 unpolluted biomixture, from 6.3 to 8.5 . However, the soil $\mathrm{pH}$ was lower than that observed in the 251 biomixtures. It was from 5.0 to 6.4 in polluted soil and unpolluted soil from 5.3 to 6.9. There was 252 no significant difference $(\mathrm{p}<0.05)$ between the levels (surface, middle, and bottom) of each of 253 the treatments. (Fig. S1).

254 The moisture was significantly higher at the bottom compared to the middle and surface levels in 255 both biomixtures and soils. In general, biomixtures had higher moisture than soils, with no 256 difference between pesticide treatments. The lowest values were found in the surface level (30 $257 \%$, soil day 35) and the highest in the bottom level (70\%, biomixture day 28$)$. Moisture was on 258 average $49 \%$ in polluted biomixtures and $52 \%$ in unpolluted biomixtures, while it was 44 and $25947 \%$ with polluted and unpolluted soils. (Fig. S2).

260 The CEC was higher in biobeds with soil as substrate; it was initially close to $62 \mathrm{cmol}(+) \mathrm{kg}^{-1}$ 261 and at the end of the experiment $86 \mathrm{cmol}(+) \mathrm{kg}^{-1}$ on average. CEC was lower in biomixtures 262 samples, close to $40 \mathrm{cmol}(+) \mathrm{kg}^{-1}$ at the begging and $\left.67 \mathrm{cmol}^{+}+\right) \mathrm{kg}^{-1}$ at the end of the 263 experiment. There was no significant difference in column levels throughout the experiment in 264 each treatment (Fig. S3).

265 Organic matter in polluted and unpolluted biomixtures were on average $20 \%$ and $18 \%$, 266 respectively. While in the polluted and unpolluted soils, it was $5 \%$ and $6 \%$, respectively. The 267 organic matter content was 3 to 4 times higher in the biomixtures than in the soils throughout the 268 experiment. Organic matter decreased in the polluted biomixtures gradually from 23 to $16 \%$. 269 This decrease was slightly higher in the unpolluted biomixture. There was no significant 270 difference in organic matter content between the levels (surface, middle, and bottom) of each 271 treatment (Fig. S4).

272 At the beginning of the experiment, the highest ETU concentration occurred at the surface level 273 of biomixtures and soils with 69 and $84 \mathrm{mg} \mathrm{kg}^{-1} \mathrm{~d}$. w., respectively. The concentration of the 274 pesticide in the biomixtures decreased continuously at the surface level. There was an increase at 27514 days in the intermediate level, while in the bottom at 14 and 28 days. On average, the 276 pesticide concentration in biomixtures was $19 \mathrm{mg} \mathrm{kg}^{-1}$ and in soils $30 \mathrm{mg} \mathrm{kg}^{-1}$. After 84 days, it 277 was found that in the biobeds with polluted biomixture, the concentration of ETU decreased to $2785.0 \mathrm{mg} \mathrm{kg}^{-1}$ in the surface level, $5.3 \mathrm{mg} \mathrm{kg}^{-1}$ in the middle, and $1.6 \mathrm{mg} \mathrm{kg}^{-1}$ in the bottom (Fig. 1). 
279 At the end of the experiment, the decrease of ETU in the polluted biomixtures was significant in 280 all three levels of the column, while in the polluted soil, the decrease was smaller (Table 2).

281

282

283

284

285

286

287

288

289

290

291

292

293

294

295

296

297

298

299

300

301

302

303

304

305

306

307

308

309

310

311

312

313

314

315

316

317

\section{Kinetics of biological parameters}

The biological variables were evaluated in the simulated biobeds with soil and biomixture for 84 days. The variables considered were microbial colonies and direct cell counts.

The addition of the pesticide in the biobeds significantly reduced microbial colonies in the treatments. The most significant impact was observed at the surface level of the biomixtures. It was found that the pesticide reduced bacterial colonies from $10 \times 10^{7}$ to $24 \times 10^{6} \mathrm{CFU} \mathrm{mL}^{-1}$ and fungi from $36 \times 10^{4}$ to $40 \times 10^{3} \mathrm{CFU} \mathrm{mL}^{-1}$ in the first seven days of exposure to the pesticide. In the middle and bottom levels of the biomixtures, a decrease in colony counts was observed on day 14. However, the number of bacterial and fungal colonies stabilized from day 42 days in all three levels. There was a significant recovery after 84 days compared to the unpolluted control. In the case of pesticide-polluted soil, the reduction in the number of bacterial colonies was higher, from $64 \times 10^{6}$ to $40 \times 10^{5} \mathrm{CFU} \mathrm{mL}^{-1}$, and in fungi from $28 \times 10^{4}$ to $40 \times 10^{3} \mathrm{CFU} \mathrm{mL}^{-1}$ ); this decrease was maintained throughout the kinetics study period at all three levels of the column (Fig. 2 and Fig. 3). After 84 days, there was no statistically significant difference between the number of bacterial cells in the polluted biomixture compared to the unpolluted biomixture in the three levels of the column. However, in fungal cells, the values are slightly lower in the polluted biomixture (Table 2).

Analogous to the colony count, the microbial cell count showed a significant impact due to the toxic effect of EBDC. The count of bacterial cells in the biomixture before the pollution was approximately $30 \times 10^{5}$ and decreased to $40 \times 10^{4} \mathrm{cells} \mathrm{mL}^{-1}$, while in fungi, it decreased from 95 $\times 10^{2}$ to $50 \times 10^{1}$ cells $\mathrm{mL}^{-1}$. In pesticide-polluted soil, bacterial cells decreased to $10 \times 10^{4}$ cells $\mathrm{mL}^{-1}$ and fungi even to none. The most significant reduction of microbial cells in polluted biomixture was observed at surface level on day 14. In the middle level, cells decreased from day 28 to 56 , while in the bottom level, from day 56 to 60 . After the decrease in the number of cells, the bacteria and fungi started showing marked recovery after about 42 days at the surface and middle level. However, fungi had a lower count in polluted samples throughout the experiment (Fig. 4 and Fig. 5).

Spearman's correlation analysis of variables was performed to identify the interaction of the parameters analyzed with microbial abundance (Table 3). It was found that there was a negative correlation between the number of microorganisms with the ETU concentration. The number of bacteria was significantly correlated with $\mathrm{pH}$ and CEC and ETU concentration, in that order. In contrast, the number of fungi had the highest significant correlation with ETU concentration, followed by $\mathrm{pH}$ and moisture. The highest correlation was ETU concentration with fungal cell count $(0.77)$. The physicochemical parameters with the highest correlation were the organic matter with CEC (0.91).

\section{Discussion}


319 All treatments increased their $\mathrm{pH}$ because aerobic and anaerobic degradation of organic matter 320 initially favored acidic processes, but as the biomixture matures, the $\mathrm{pH}$ tends to become alkaline

321 (Tortella et al. 2012). The absence of differences in $\mathrm{pH}$ of the three levels of all treatments can be 322 explained by the fact that the length of the column was not long enough for a gradient to form.

323 The organic matter degradation due to microbial activity could explain the $\mathrm{pH}$ variations in 324 treatment (Gao et al. 2015). The most significant degradation of ETU occurred at near-neutral

325

326

327

328

329

330

331

332

333

334

335

336

337

338

339

340

341

342

343

344

345

346

347

348

349

350

351

352

353

354

355

356

357

358 $\mathrm{pH}$. According to Castro et al. (2017), the pesticide oxamyl is rapidly hydrolyzed in soils with neutral $\mathrm{pH}$, whereas it is slowly degraded in alkaline soils and with difficulty in acidic soils. According to Vareli et al. (2018), the $\mathrm{pH}$ influences the sorption and mobility of pesticides. It was found that the biomixture alkalinization coincides with the ETU mobility from the surface to the bottom. Also, microbial populations are selected by the $\mathrm{pH}$ range of the biomixture. The increase in $\mathrm{pH}$ contributed to the decrease in the number of fungi. According to Vischetti et al. (2007) a slightly acidic $\mathrm{pH}$ may favor fungal activity, while the alkaline $\mathrm{pH}$ favors bacterial activity.

The cationic exchange capacity depends on the amount of clay and organic matter in the biomixture and soil (Benito et al. 2005). A soil with elevated CEC has a higher sorption capacity for pesticides (Adak et al. 2020; Karanasios et al. 2010). However, if an excess of solutes saturates the sorption sites, the soil loses its sorption capacity (Li et al. 2006). It has been described that the CEC suitable for the degradation of pesticides should be lower than 60 cmol $(+) \mathrm{kg}^{-1}$ (Domínguez et al. 2021). The CEC in the biomixtures allowed the ETU sorption in the middle and bottom of the biobeds until degradation.

The biomixtures retained adequate moisture throughout the experiment (35-65\%); however, the values varied considerably at the different depth levels in the biobeds. The columns formed a moisture gradient because the high temperatures at the site favored the evaporation of the substrates. According to Coppola et al. (2007) the soil moisture content considered adequate for aeration and optimal microbial activity is $60 \%$. However, it is crucial to avoid water saturation of the biomixture, as this would negatively affect the biodegradation process, with the risk of pesticides migrating out of the biobed (Torstensson 2000). Like pH, the humidity of the middle and bottom levels may have been a factor influencing the mobility of ETU from the surface to the bottom of the biobeds since ETU is highly soluble in water (Ruiz Suárez et al. 2013). Diez et al. (2017) considered that the appropriate organic matter content for pesticide degradation in the biomixture should be higher than $30 \%$, which was not achieved in the experimental units of the experiment. This could be because the biomixture was not made from peat or compost, although the results were satisfactory in pesticide degradation. However, the organic matter content was higher than commonly found in soils of 1-6\%. (Vischetti et al. 2008). The treatments polluted with EBDC had a lower reduction in organic matter, possibly due to the toxic effect of the pesticide and subsequent reduction in microbial activity. There was no difference between the three levels of the column in all the treatments; this could be because the column length was not long enough to form a gradient. A high content of carbon-rich organic matter is essential because it increases the sorption capacity of the biomixture, preventing the 
359

360

361

362

363

364

365

366

367

368

369

370

371

372

373

374

375

376

377

378

379

380

381

382

383

384

385

386

387

388

389

390

391

392

393

394

395

396

397

formation of toxic leachates (Kravvariti et al. 2010). It has been described that biomixtures could have a pesticide retention capacity of up to $85 \%$ higher than most soils, so in biobeds, xenobiotics were retained in the upper layers and migrated slowly to the lower levels (Delgado et al. 2017). The biomixture used was made up of $33 \%$ banana stem as an organic matter source. This material is rich in lignin (17\%), cellulose (50\%), and hemicellulose (15\%) (Abdullah et al. 2013). The biomixture should have a high lignin content so that the fungi produce the ligninolytic enzymes (laccases and peroxidases) that degrade the organic complexes (Delgado et al. 2017; Romero et al. 2019). Lignocellulosic materials also supply carbon and nitrogen required for microbial growth (Jia et al. 2017; Romero et al. 2019). In this respect, the banana stem consists of up to $74 \%$ of its dry weight of organic carbon (Abdullah et al. 2013), while the biomixture had $48 \%$ carbon. According to (Castro et al. 2017), the decrease of the carbon content in the biomixture causes a reduction of respiration and microbial activity; this may indicate the loss of the pesticide's degradation capacity or aging of the biomixture.

The initial concentration of the pesticide in this research was $1,000 \mathrm{mg} \mathrm{L}^{-1}$, which can be considered high since most studies evaluating the degradation of pesticides in biobeds have used concentrations lower than $200 \mathrm{mg} \mathrm{L}^{-1}$. In the literature review, only three studies with similar concentrations were found. In the research conducted by Gao et al. (2015), imidacloprid (1,000 $\mathrm{mg} \mathrm{L}^{-1}$ ) was degraded with a biomixture prepared with wheat straw, spend mushroom, and soil $(2: 1: 1 \mathrm{v})$. Perruchon et al. (2015) reported $80 \%$ degradation of o-phenylphenol $\left(1,000 \mathrm{mg} \mathrm{L}^{-1}\right)$ in 37 days in polluted soil. While, Lescano et al. (2020) found that a $90 \%$ degradation of glyphosate after 90 days $\left(1,000 \mathrm{mg} \mathrm{kg}^{-1}\right)$ with a biomixture prepared with river residues, alfalfa, and wheat straws.

EBDC is poorly soluble $\left(16 \mathrm{mg} \mathrm{L}^{-1}\right)$ and has a high soil adsorption coefficient $\left(\mathrm{K}_{\mathrm{oc}}=363-2,334\right.$ $\left.\mathrm{cm}^{3} \mathrm{~g}^{-1}\right)$, however, ETU has a low soil sorption coefficient $\left(\mathrm{K}_{\mathrm{oc}}=34-146 \mathrm{~cm}^{3} \mathrm{~g}^{-1}\right)$ and is highly soluble $\left(20,000 \mathrm{mg} \mathrm{L}^{-1} 30^{\circ} \mathrm{C}\right)$. (Mackay et al. 2006). Therefore, ETU is a highly mobile metabolite upon contact with water. This mobility may explain the increase in ETU concentration in the middle and bottom levels of the biobeds from day 14 to 42; namely, the pesticide gradually migrated from the surface to the bottom in polluted biomixture due to higher humidity in the middle and bottom levels. The mobility of pesticides in biobeds will depend on the soil's sorption capacity, water solubility, and pH. Highly soluble pesticides with low sorption capacity tend to move through the soil, which decreases the residence time and the chances of being degraded by microorganisms (Vareli et al. 2018).

EBDC is known to degrade to ETU by photolysis in two days at $30^{\circ} \mathrm{C}$ with normal atmospheric oxygen levels. On the other hand, ETU has a half-life of 1-9 days by photolysis (Nikunen et al. 2000). However, it has been reported that EBDC concentration $>20 \mathrm{mg} \mathrm{L}^{-1}$ in the soil can take 90-100 days to mineralize (Cruickshank \& Jarrow 1973). This report coincides with the degradation time found in the present research of 84 days. The ETU concentration at the end of the kinetics study period was close to the maximum residue limit established for food (tomato) of $2 \mathrm{mg} \mathrm{kg}^{-1}$ day $^{-1}$ by the FAO (Atuhaire et al. 2017) and close to the median lethal dose defined for 
398

399

400

401

402

403

404

405

406

407

408

409

410

411

412

413

414

415

416

417

418

419

420

421

422

423

424

425

426

427

428

429

430

431

432

433

434

435

436

437

crustaceans (Daphnia magna) and fish (Salmo gairdneri) of 1.3 and $1.9 \mathrm{mg} \mathrm{L}^{-1}$ respectively (Nikunen et al. 2000).

The pesticide addition in biomixtures caused a reduction of $72 \%$ in bacterial and $73 \%$ in fungal colonies at the surface level at the experiment's beginning. The pesticide toxicity was not observed in the middle and bottom levels until day 14 and then remained constant, possibly due to the mobilization of ETU from the surface to the bottom. The recovery of microbial populations on day 42 can be attributed to the reduction of toxicity at all three levels of the biomixture. At that time, the ETU concentration at the surface was $22 \mathrm{mg} \mathrm{kg}^{-1}$, in the middle 35 $\mathrm{mg} \mathrm{kg}^{-1}$, and at the bottom $10 \mathrm{mg} \mathrm{kg}^{-1}$. These values are lower than the half-maximal effective concentration $\left(\mathrm{EC}_{50}\right.$ ) calculated for microorganisms of $38 \mathrm{mg} \mathrm{kg}^{-1}$. (Van Leeuwen et al. 1985). Bacteria showed better adaptability to high pesticide concentrations than fungi. At the end of the experiment, the bacterial colony count in polluted and unpolluted biomixture was similar. The case of fungi had a significant reduction in the number of colonies between days 42 and 56 . On the other hand, the reduction of colonies in polluted soil was very significant, $93 \%$ in bacteria and $85 \%$ in fungi. Results similar to those of this research were reported by Diez et al. (2017) on the degradation of $40 \mathrm{mg} \mathrm{kg}^{-1}$ atrazine with a biomixture of wheat straw, peat, and soil. It was found that bacteria and fungi were strongly affected by atrazine, but microbial populations recovered after 40 days. It was concluded that pesticide presence might have stimulated the growth of fungi capable of degrading the toxic compound. Also, it was considered that bacteria and actinobacteria could be associated with fungal populations in mineralizing the toxic compound in biobeds.

Few studies have evaluated the effect of pesticides on colony microbial counts. For example, Tortella et al. (2013) evaluated the effect of three doses of atrazine on the microbial population in a Swedish biomixture for 60 days. There was no difference in the number of bacterial and actinomycetes colonies compared to the control. The colony count was in the range of $14 \times 10^{6}$ to $45 \times 10^{6} \mathrm{CFU} \mathrm{g}^{-1}$ in bacteria and $15 \times 10^{5}$ to $30 \times 10^{5} \mathrm{CFU} \mathrm{g}^{-1}$ in actinomycetes. The number of fungal colonies decreased significantly compared to the control, with values from $21 \times 10^{4}$ to $75 \times 10^{4} \mathrm{CFU} \mathrm{g}^{-1}$. It was concluded that fungi were more sensitive than bacteria and actinomycetes to atrazine. In comparison, Góngora et al. (2020) analyzed an inoculated biomixture with Ochrobactrum spp. and Pseudomonas citronellolis and polluted with 2,4dichlorophenol, carbofuran, diazinon, and glyphosate (50 $\mathrm{mg} \mathrm{L}^{-1}$ each). Pesticides were degraded in 10 days, and the bacteria increased from $32 \times 10^{6}$ to $85 \times 10^{6} \mathrm{CFU} \mathrm{g}^{-1}$ in five days.

The organic matter content of the biomixtures supported a higher microbial population compared to soils, which contributed to pesticide degradation. However, the microbial population may decrease to a level that may not contribute to pesticide degradation. In the kinetic study, the most significant decrease in microbial population coincided with the highest ETU concentration in the three levels of the polluted biomixture at 42 days with 42 to $48 \times 10^{6} \mathrm{CFU} \mathrm{mL}^{-1}$ in bacteria and $80 \times 10^{3}$ to $16 \times 10^{4} \mathrm{CFU} \mathrm{mL}^{-1}$ in fungi. This value in the polluted biomixture was similar to that in the unpolluted soil, 38-44 x $10^{6} \mathrm{CFU} \mathrm{mL}^{-1}$ in bacteria, $13-22 \times 10^{4} \mathrm{CFU} \mathrm{mL}^{-1}$ in fungi. Based on the above, it is possible to infer that the required bacterial population to achieve EBDC 
438 degradation must be greater than $40 \times 10^{6} \mathrm{CFU} \mathrm{mL}^{-1}$ and the fungal population greater than $80 \mathrm{x}$ $43910^{3} \mathrm{CFU} \mathrm{mL} \mathrm{m}^{-1}$.

440 The cell count had a behavior analogous to the colony count. The addition of the pesticide 441 caused a $69 \%$ reduction in bacterial cells and an $89 \%$ reduction in fungal cells at the surface 442 level in the first 14 days in the polluted biomixtures. In the middle and bottom levels, the 443 reduction on microbial cells was greater following the increase in ETU concentration. The 444 stabilization of the number of bacterial cells was noticeable from day 42 of monitoring and in 445 fungi less significantly. The number of bacteria fully recovered after 84 days while fungi were 446 slightly lower, which is related to the dissipation of the pesticide in the three levels of the biobed. 447 The difference in response between bacteria and fungi could be due to the chemical nature of the 448 pesticide and that the greater diversity of bacteria favors the selection and growth of tolerant 449 species. Other studies have also found greater sensitivity of fungi than bacteria to some

450

451

452

453

454

455

456

457

458

459

460

461

462

463

464

465

466

467

468

469

470

471

472

473

474

475

476

477

pesticides. For example, Campos et al. (2017) analyzed in a Swedish biomixture the iprodione degradation ( $90.9 \mathrm{mmol} \mathrm{kg}^{-1}$ ). It was concluded that the addition of the pesticide caused a decrease in fungal species abundance, but bacteria and actinobacteria adapted quickly. Elgueta et al. (2017) evaluated the degradation of atrazine, chlorpyrifos, and iprodione (35 mg $\left.\mathrm{kg}^{-1}\right)$. It was found that all microbial groups were affected in soil, while in biomixtures only fungi.

Some studies have used cell counting to evaluate biomixtures, Goux et al. (2003) report that a sterile Swedish biomixture polluted with atrazine $\left(10 \mathrm{mg} \mathrm{g}^{-1}\right)$ was inoculated with $575 \mathrm{cell}^{-1}$ of microbial soil consortia. After 28 days, it had a concentration of $15 \times 10^{3}$ cell g$^{-1}$. Sniegowski et al. (2012) estimated that the minimum number of cells needed to remediate a linuron $60 \mathrm{mg} \mathrm{L}^{-1}$ in a Swedish biomixture is $45 \times 10^{1}$ bacterial cells $\mathrm{g}^{-1}$.

The highest decrease of microbial cells was at 42 days with a range of $50 \times 10^{4}$ to $13 \times 10^{5}$ cells $\mathrm{mL}^{-1}$ in bacteria and $80 \times 10^{1}$ to $26 \times 10^{2}$ cells $\mathrm{mL}^{-1}$ in fungi. This value in the polluted biomixture was similar to that in the unpolluted soil, 58 to $88 \times 10^{4}$ cells $\mathrm{mL}^{-1}$ in bacteria, 15 to $25 \times 10^{2}$ cells $\mathrm{mL}^{-1}$ in fungi. Analogously to the minimum colony number, it can be stated that the number of cells that could be necessary for EBDC degradation should be higher than $50 \mathrm{x}$ $10^{4}$ cells $\mathrm{mL}^{-1}$ in bacteria and $80 \times 10^{1}$ cells $\mathrm{mL}^{-1}$ in fungi. This value can help to indicate if the biomixture is aged; in this case, it should be replaced by a new biomixture. The suggested minimum number of microbial colonies and cells should be limited to biomixtures with similar characteristics in organic matter content exposed to a warm-humid environment.

The correlation analysis found that the number of bacterial colonies and cells is mainly affected by $\mathrm{pH}$ and $\mathrm{CEC}$, followed by ETU concentration. In contrast, the number of fungal colonies and cells is mainly affected by ETU concentration followed by $\mathrm{pH}$ and moisture. It can be said that the degradation of ETU is simultaneously influenced by microbial activity, $\mathrm{pH}$, moisture, and organic matter content. The abundance of fungi showed a higher correlation and sensitivity than bacteria to ETU concentration so that they could be used as indicators of EBDC degradation in biomixtures. The results demonstrate that colony count and cell count can be used to monitor the pesticide degradation process in biobeds, but without neglecting the analysis of other variables such as organic matter content, $\mathrm{pH}, \mathrm{CEC}$, and pesticide concentration.

Peer) reviewing PDF | (2021:02:57885:2:0:NEW 12 Aug 2021) 
478 Few investigations have analyzed the interaction between physicochemical and biological

479 parameters in biobeds. In the research conducted by Góngora et al. (2017) in evaluating 11 types

480 of biomixtures polluted with a mixture of five pesticides, he found that the concentration of

481 residual pesticide has a relatively significant negative correlation with $\mathrm{pH}$, lignin, $\mathrm{C} / \mathrm{N}$ ratio, and

482 water holding capacity. At the same time, with organic matter and nitrogen content, the

483 correlation was less significant. This research concurred in finding that ETU concentration

484 correlates strongly with $\mathrm{pH}$ and moisture, and to a lesser extent, with organic matter content. On

485 the other hand, Góngora et al. (2018) evaluated biomixtures polluted with atrazine, carbofuran,

486 diazinon, and glyphosate $\left(12.50,0.23,0.34\right.$, and $\left.0.36 \mathrm{mg} \mathrm{cm}^{-3}\right)$ exposed to a tropical climate.

487 Twenty-three species of Archeobacteria, 598 species of bacteria, and 64 species of fungi were

488 identified. Their research results pointed out that the archeobacteria diversity was correlated with

$489 \mathrm{pH}$ and carbon/nitrogen ratio. In contrast, the bacteria diversity was correlated with lignin and

490 organic matter content, while the fungal diversity with lignin content and water holding capacity.

491 Evaluation of microbiological parameters is necessary to understand the degradation kinetics of

492 pesticides in biobeds (Vischetti et al. 2008). The pesticides alter the distribution and abundance

493 of the microbial population. The significant impact occurs immediately upon contact with the

494 pesticide, but if the dose is not excessively high, microbial populations may recover in a short

495 time (Diez et al., 2017). However, there will be less impact on biomixtures than in soil without

496 organic amendments. This buffering of the toxic effect of pesticides is attributed to an increase in

497 the sorption capacity of the matrix, as well as to the use of nutrients that come from the

498 degradation of organic substrates by the microorganisms (Delgado-Moreno et al. 2019; Elgueta

499 et al. 2017; Wang et al. 2014). Thus, selecting appropriate materials will influence the abundance

500 of microorganisms with the capacity to degrade pesticides (Vareli et al. 2018).

501 Colony and cell counting have advantages over other techniques for assessing microbial activity.

502 Enzyme activity assays and genetic profiling require expensive equipment or reagents. Genetic

503 profiling helps establish diversity but does not quantify abundance. Moreover, just because a

504 species is identified in a genetic profile does not indicate that it is metabolically active. On the

505 other hand, biomass determination does not allow differentiation between microbial groups.

506 Finally, colony and cell counts are relatively easy to measure, do not require expensive

507 equipment, and are sensitive to pesticide variations.

508

\section{Conclusions}

510 The biomixture based on banana stem, mulch, and Fluvisol soil (50:25:25 \% v/v) supported the

511 microbial activity necessary to degrade the EBDC pesticide. This made it possible to take

512 advantage of local materials and ensure the degradation of contaminants. It was found that a dose

513 of $1,000 \mathrm{mg} \mathrm{L}^{-1}$ reduced the number of microbial colonies by $72 \%$. The number of bacterial

514 cells decreased by $69 \%$ and fungi by $89 \%$ on the surface. ETU diffused to the bottom of the

515 biofield, altering microbial distribution and abundance. The time required by the microorganisms

516 to stabilize their populations after exposure to the EBDC compound was approximately 42 days.

517 After 84 days, significant degradation of ETU was achieved at all three levels of the biomixture, 
$5181.6 \mathrm{mg} \mathrm{kg}^{-1}$ at the bottom and slightly higher at the middle and surface (5.0 and $\left.5.3 \mathrm{mg} \mathrm{kg}^{-1}\right)$. At 519 the end of the experiment, the bacteria showed significant recovery from the toxic effect of

520 EBDC, but not the fungi. It was found that there is a strong correlation between ETU

521 concentration and fungal counts; therefore, they could be used as indicators of the degradation

522 process.

523 From the microbial growth kinetics, it was possible to establish the minimum populations

524 necessary for pesticide degradation. In terms of microbial colonies, it was $40 \times 10^{6} \mathrm{CFU} \mathrm{mL}^{-1}$ in

525 bacteria and $80 \times 10^{3} \mathrm{CFU} \mathrm{mL}^{-1}$ in fungi. While in microbial cells, it was set at $50 \times 10^{4}$ cells

$526 \mathrm{~mL}^{-1}$ in bacteria and $80 \times 10^{1}$ cells $\mathrm{mL}^{-1}$ in fungi. The microbial count can be used to know if the

527 biomixture should be replaced when its capacity to maintain microbial activity is exhausted.

528 From the experimental results obtained in this research, it can be concluded that it is appropriate

529 to include the quantification of microbial populations to assess the effectiveness of pesticide

530 degradation and the lifetime of the biomixture. In this regard, the microbial colony and cell

531 counting techniques used in this experimental work were convenient due to their low cost, ease

532 of measurement, and sensitivity to pesticide variations. The microbial count made it possible to

533 identify pesticide mobility within the biobed, the time required for degradation, and whether the

534 microbial population is sufficient to support new doses of pesticides. Based on the found results,

535 it is recommended to continue the research in the following aspects:

536 - The identification of indigenous microorganisms with the potential to degrade specific

537 pesticides.

538 Establishing the biomixture useful lifetime under continuous application of the pesticide

539 conditions.

540 - The mechanism of tolerance to pesticides by the microorganisms and metabolic processes

541 involved in the degradation.

542

543 Acknowledgments

544 To the "Cátedras CONACyT" Program in Mexico, Consejo Nacional de Ciencia y Tecnología,

545 Project \#240 “Microbiología de camas biológicas para tratamiento de aguas residuales del cultivo

546 de plátano”.

\section{References}

548 Abdullah N, Sulaiman F, and Taib RM. 2013. Characterization of banana (Musa spp.) plantation wastes

549

550

551

552

553

554

555

556 as a potential renewable energy source. AIP Conference Proceedings 1528:325-330. https://doi.org/10.1063/1.4803618

Adak T, Mahapatra B, Swain H, Patil NB, Pandi G GP, Gowda GB, Annamalai M, Pokhare SS, Meena S, Rath PC, and Jena M. 2020. Indigenous biobed to limit point source pollution of imidacloprid in tropical countries. Journal of Environmental Management 272:111084. https://doi.org/10.1016/j.jenvman.2020.111084

Atlas RM. 2005. Handbook of media for environmental microbiology. Boca Raton: CRC Press. https://doi.org/10.1201/9781420037487 
557

558

559

560

561

562

563

564

565

566

567

568

569

570

571

572

573

574

575

576

577

578

579

580

581

582

583

584

585

586

587

588

589

590

591

592

593

594

595

596

597

598

599

600

601

602

603

604

605

606
Atuhaire A, Kaye E, Mutambuze IL, Matthews G, Friedrich T, and Jørs E. 2017. Assessment of dithiocarbamate residues on tomatoes conventionally grown in Uganda and the effect of simple washing to reduce exposure risk to consumers. Environmental Health Insights 11:1178630217712218. https://doi.org/10.1177/1178630217712218

Benito M, Masaguer A, Moliner A, Arrigo N, Palma RM, and Effron D. 2005. Evaluation of maturity and stability of pruning waste compost and their effect on carbon and nitrogen mineralization in soil. Soil Science 170:360-370. https://doi.org/10.1097/01.ss.0000169909.87237.c5

Campos M, Perruchon C, Karas PA, Karavasilis D, Diez MC, and Karpouzas DG. 2017. Bioaugmentation and rhizosphere-assisted biodegradation as strategies for optimization of the dissipation capacity of biobeds. Journal of Environmental Management 187:103-110. https://doi.org/10.1016/j.jenvman.2016.11.031

Castillo MdP, and Torstensson L. 2007. Effect of biobed composition, moisture, and temperature on the degradation of pesticides. Journal of Agricultural and Food Chemistry 55:5725-5733. https://doi.org/10.1021/jf0707637

Castro V, Masís M, Diez MC, Tortella GR, and Rodríguez CE. 2017. Aging of biomixtures: effects on carbofuran removal and microbial community structure. Chemosphere 168:418-425. https://doi.org/10.1016/j.chemosphere.2016.10.065

Coppola L, Castillo MdP, Monaci E, and Vischetti C. 2007. Adaptation of the biobed composition for chlorpyrifos degradation to southern Europe conditions. Journal of Agricultural and Food Chemistry 55:396-401. https://doi.org/10.1021/jf062744n

Cruickshank PA, and Jarrow HC. 1973. Ethylenethiourea degradation. Journal of Agricultural and Food Chemistry 21:333-335. https://doi.org/10.1021/jf60187a048

De Vos B, Lettens S, Muys B, and Deckers JA. 2007. Walkley-Black analysis of forest soil organic carbon: recovery, limitations and uncertainty. Soil Use Management 23:221-229. https://doi.org/10.1111/j.1475-2743.2007.00084.x

Delgado-Moreno L, Bazhari S, Nogales R, and Romero E. 2019. Innovative application of biobed bioremediation systems to remove emerging contaminants: Adsorption, degradation and bioaccesibility. Science of the Total Environment 651:990-997. https://doi.org/10.1016/j.scitotenv.2018.09.268

Delgado L, Bazhari S, Nogales R, and Romero E. 2019. Innovative application of biobed bioremediation systems to remove emerging contaminants: Adsorption, degradation and bioaccesibility. Science of the Total Environment 651:990-997. https://doi.org/10.1016/j.scitotenv.2018.09.268

Delgado L, Nogales R, and Romero E. 2017. Biodegradation of high doses of commercial pesticide products in pilot-scale biobeds using olive-oil agroindustry wastes. Journal of Environmental Management 204:160-169. https://doi.org/10.1016/j.jenvman.2017.08.032

Diez MC, Elgueta S, Rubilar O, Tortella GR, Schalchli H, Bornhardt C, and Gallardo F. 2017. Pesticide dissipation and microbial community changes in a biopurification system: influence of the rhizosphere. Biodegradation 28:395-412. https://doi.org/10.1007/s10532-017-9804-y

Domínguez V, Obrador JJ, Adams RH, Zavala J, Vaquera H, Guerrero A, and Miranda E. 2015. Occupational and environmental risks from mancozeb in aviation facilities in the banana producing area of Teapa, Tabasco, Mexico. Tropical Journal of Pharmaceutical Research 14:1703-1712. https://doi.org/10.4314/tjpr.v14i9.23

Domínguez VI, Obrador JJ, Zavala J, Baltierra E, Ramos S, Rosique JE, and Adams RH. 2021. Substrate evaluation for biobeds in the degradation of ethylene bis-dithiocarbamate in wastewater from pesticide application in banana. Journal of Environmental Health Science \& Engineering. https://doi.org/10.1007/s40201-020-00595-5

Drenth A, and Guest DI. 2016. Fungal and oomycete diseases of tropical tree fruit crops. Annual Review of Phytopathology 54:373-395. https://doi.org/10.1146/annurev-phyto-080615-095944

Dzionek A, Wojcieszyńska D, and Guzik U. 2016. Natural carriers in bioremediation: A review. Electronic Journal of Biotechnology 19:28-36. https://doi.org/10.1016/j.ejbt.2016.07.003 
607

608

609

610

611

612

613

614

615

616

617

618

619

620

621

622

623

624

625

626

627

628

629

630

631

632

633

634

635

636

637

638

639

640

641

642

643

644

645

646

647

648

649

650

651

652

653

654

655

656

Elgueta S, Correa A, Campo M, Gallardo F, Karpouzas D, and Diez MC. 2017. Atrazine, chlorpyrifos, and iprodione effect on the biodiversity of bacteria, actinomycetes, and fungi in a pilot biopurification system with a green cover. Journal of Environmental Science and Health, Part B 52:651-657. https://doi.org/10.1080/03601234.2017.1330070

FAO. 2019. FAOSTAT statistical database. 2020-07-29 ed. Rome: Food and Agriculture Organization of the United Nations

Gao W, Liang J, Pizzul L, Feng XM, Zhang K, and Castillo MdP. 2015. Evaluation of spent mushroom substrate as substitute of peat in Chinese biobeds. International Biodeterioration \& Biodegradation 98:107-112. https://doi.org/10.1016/j.ibiod.2014.12.008

Garman M, and Hesse PR. 1975. Cation exchange capacity of gypsic soils. Plant and Soil 42:477-480. https://doi.org/10.1007/BF00010022

Geissen V, Ramos FQ, Bastidas-Bastidas PdJ, Díaz-González G, Bello-Mendoza R, Huerta-Lwanga E, and Ruiz-Suárez LE. 2010. Soil and water pollution in a banana production region in tropical Mexico. Bulletin of environmental contamination and toxicology 85:407-413. https://doi.org/10.1007/s00128-010-0077-y

Góngora VR, García R, Rojas R, Giácoman G, and Ponce C. 2020. Pesticide bioremediation in liquid media using a microbial consortium and bacteria-pure strains isolated from a biomixture used in agricultural areas. Ecotoxicology and Environmental Safety 200:110734. https://doi.org/10.1016/j.ecoenv.2020.110734

Góngora VR, Martin F, Quintal C, Giácoman G, and Ponce C. 2017. Agricultural effluent treatment in biobed systems using novel substrates from southeastern Mexico: the relationship with physicochemical parameters of biomixtures. Environmental Science and Pollution Research 24:9741-9753. https://doi.org/10.1007/s11356-017-8643-z

Góngora VR, Quintal C, Arena ML, Giácoman G, and Ponce C. 2018. Identification of microbial species present in a pesticide dissipation process in biobed systems using typical substrates from southeastern Mexico as a biomixture at a laboratory scale. Science of the Total Environment 628:528-538. https://doi.org/10.1016/j.scitotenv.2018.02.082

Goux S, Shapir N, Fantroussi SE, Lelong S, Agathos SN, and Pussemier L. 2003. Long-term maintenance of rapid atrazine degradation in soils inoculated with atrazine degraders. Water, Air, \& Soil Pollution 3:131-142. https://doi.org/10.1023/A:1023998222016

Gupta PK. 2018. Chapter 45 - Toxicity of Fungicides. In: Gupta RC, ed. Veterinary Toxicology (Third Edition): Academic Press, 569-580. https://doi.org/10.1016/B978-0-12-811410-0.00045-3

Jia Z, Deng J, Chen N, Shi W, Tang X, and Xu H. 2017. Bioremediation of cadmium-dichlorophen cocontaminated soil by spent Lentinus edodes substrate and its effects on microbial activity and biochemical properties of soil. Journal of Soils Sediments 17:315-325. https://doi.org/10.1007/s11368-016-1562-7

Karanasios E, Tsiropoulos NG, Karpouzas DG, and Menkissoglu-Spiroudi U. 2010. Novel biomixtures based on local Mediterranean lignocellulosic materials: evaluation for use in biobed systems. Chemosphere 80:914-921. https://doi.org/10.1016/j.chemosphere.2010.06.003

Kravvariti K, Tsiropoulos NG, and Karpouzas DG. 2010. Degradation and adsorption of terbuthylazine and chlorpyrifos in biobed biomixtures from composted cotton crop residues. Pest Management Science 66:1122-1128. https://doi.org/10.1002/ps.1990

Lescano MR, Masin CE, Rodríguez AR, Godoy JL, and Zalazar CS. 2020. Earthworms to improve glyphosate degradation in biobeds. Environmental Science and Pollution Research 27:2702327031. https://doi.org/10.1007/s11356-020-09002-w

Li H, Teppen BJ, Laird DA, Johnston CT, and Boyd SA. 2006. Effects of increasing potassium chloride and calcium chloride ionic strength on pesticide sorption by potassium-and calcium-smectite. Soil Science Society of America Journal 70:1889-1895. https://doi.org/10.2136/sssaj2005.0392

Mackay D, Shiu W-Y, and Lee SC. 2006. Handbook of physical-chemical properties and environmental fate for organic chemicals: CRC press.

Peer) reviewing PDF | (2021:02:57885:2:0:NEW 12 Aug 2021) 
657

658

659

660

661

662

663

664

665

666

667

668

669

670

671

672

673

674

675

676

677

678

679

680

681

682

683

684

685

686

687

688

689

690

691

692

693

694

695

696

697

698

699

700

701

702

703

704

705

706

707

Mew EJ, Padmanathan P, Konradsen F, Eddleston M, Chang S-S, Phillips MR, and Gunnell D. 2017. The global burden of fatal self-poisoning with pesticides 2006-15: systematic review. Journal of Affective Disorders 219:93-104. https://doi.org/10.1016/j.jad.2017.05.002

Morillo E, and Villaverde J. 2017. Advanced technologies for the remediation of pesticide-contaminated soils. Science of the Total Environment 586:576-597. https://doi.org/10.1016/j.scitotenv.2017.02.020

Mueller GM, Bills G, and Foster MS. 2011. Biodiversity of fungi: inventory and monitoring methods. Burlington: Elsevier Academic Press. https://doi.org/10.1663/00130001(2005)059[0087:BOFIAM]2.0.CO;2

Mukherjee S, Tappe W, Weihermueller L, Hofmann D, Köppchen S, Laabs V, Schroeder T, Vereecken H, and Burauel P. 2016. Dissipation of bentazone, pyrimethanil and boscalid in biochar and digestate based soil mixtures for biopurification systems. Science of the Total Environment 544:192-202. https://doi.org/10.1016/j.scitotenv.2015.11.111

Nikunen E, Leinonen R, Kemiläinen B, and Kultamaa A. 2000. Environmental properties of chemicals. Volume 2.

Pansu M, and Gautheyrou J. 2007. Handbook of soil analysis: mineralogical, organic and inorganic methods. Springer Science \& Business Media.

Perruchon C, Batianis C, Zouborlis S, Papadopoulou ES, Ntougias S, Vasileiadis S, and Karpouzas DG. 2015. Isolation of a diphenylamine-degrading bacterium and characterization of its metabolic capacities, bioremediation and bioaugmentation potential. Environmental Science and Pollution Research 22:19485-19496. https://doi.org/10.1007/s11356-015-5132-0

Rea WJ, and Patel KD. 2017. Pesticides and chronic diseases. Reversibility of chronic disease and hypersensitivity. 1st ed. Boca Ratón: CRC Press, 649-904. https://doi.org/10.1201/9781315374826

Romero E, Delgado L, and Nogales R. 2019. Pesticide dissipation and enzyme activities in ungrassed and grassed biomixtures, composed of winery wastes, used in biobed bioremediation systems. Water, Air, \& Soil Pollution 230:33. https://doi.org/10.1007/s11270-019-4093-1

Ruiz Suárez LE, Geissen V, Jarquín Sánchez A, Castro Chan RA, and Bello Mendoza R. 2013. Formation and decay of ethylenethiourea (ETU) in soil and water under tropical conditions. Journal of Plant Nutrition and Soil Science 176:40-46. https://doi.org/10.1002/jpln.201200014

Sniegowski K, Bers K, Ryckeboer J, Jaeken P, Spanoghe P, and Springael D. 2012. Minimal pesticideprimed soil inoculum density to secure maximum pesticide degradation efficiency in on-farm biopurification systems. Chemosphere 88:1114-1118. https://doi.org/10.1016/j.chemosphere.2012.04.057

Todt CE, Bailey DC, Pressley AS, Orfield SE, Denney RD, Snapp IB, Negga R, Bailey AC, Montgomery KM, Traynor WL, and Fitsanakis VA. 2016. Acute exposure to a Mn/Zn ethylene-bisdithiocarbamate fungicide leads to mitochondrial dysfunction and increased reactive oxygen species production in Caenorhabditis elegans. NeuroToxicology 57:112-120. https://doi.org/10.1016/j.neuro.2016.09.011

Torstensson L. 2000. Experiences of biobeds in practical use in Sweden. Pesticide Outlook 11:206-211. https://doi.org/10.1039/B008025J

Tortella GR, Mella RA, Sousa DZ, Rubilar O, Acuña JJ, Briceño G, and Diez MC. 2013. Atrazine dissipation and its impact on the microbial communities and community level physiological profiles in a microcosm simulating the biomixture of on-farm biopurification system. Journal of Hazardous Materials 260:459-467. https://doi.org/10.1016/j.jhazmat.2013.05.059

Tortella GR, Rubilar O, Castillo MdP, Cea M, Mella R, and Diez MC. 2012. Chlorpyrifos degradation in a biomixture of biobed at different maturity stages. Chemosphere 88:224-228. https://doi.org/10.1016/j.chemosphere.2012.02.072

Van Leeuwen CJ, Maas-Diepeveen JL, Niebeek G, Vergouw WHA, Griffioen PS, and Luijken MW. 1985. Aquatic toxicological aspects of dithiocarbamates and related compounds. I. Short-term toxicity tests. Aquatic Toxicology 7:145-164. https://doi.org/10.1016/S0166-445X(85)80002-3

Peer) reviewing PDF | (2021:02:57885:2:0:NEW 12 Aug 2021) 
708

709

710

711

712

713

714

715

716

717

718

719

720

721

722

723

724
Vareli CS, Pizzutti IR, Gebler L, Cardoso CD, Gai DSH, and Fontana MEZ. 2018. Analytical method validation to evaluate dithiocarbamates degradation in biobeds in South of Brazil. Talanta 184:202-209. https://doi.org/10.1016/j.talanta.2018.03.009

Vischetti C, Coppola L, Monaci E, Cardinali A, and Castillo MdP. 2007. Microbial impact of the pesticide chlorpyrifos on Swedish and Italian biobeds. Agronomy for Sustainable Development 27:267-272. https://doi.org/10.1051/agro:2007020

Vischetti C, Monaci E, Cardinali A, Casucci C, and Perucci P. 2008. The effect of initial concentration, co-application and repeated applications on pesticide degradation in a biobed mixture. Chemosphere 72:1739-1743. https://doi.org/10.1016/j.chemosphere.2008.04.065

Wang F, Yao J, Chen H, Yi Z, and Choi MMF. 2014. Influence of short-time imidacloprid and acetamiprid application on soil microbial metabolic activity and enzymatic activity. Environmental Science and Pollution Research 21:10129-10138. https://doi.org/10.1007/s11356014-2991-8

Yuen SH, and Pollard AG. 1954. Determination of nitrogen in agricultural materials by the nessler reagent. II.-Micro-determinations in Plant Tissue and in Soil Extracts. Journal of the Science of Food and Agriculture 5:364-369. https://doi.org/10.1002/jsfa.2740050803 
Figure 1

Kinetics of ethylenethiourea degradation at three depths in a biobed with soil and biomixture.

Error bars represent the standard deviation of three replications. 
Contaminated biomixture $\quad--\infty-$ Contaminated soil

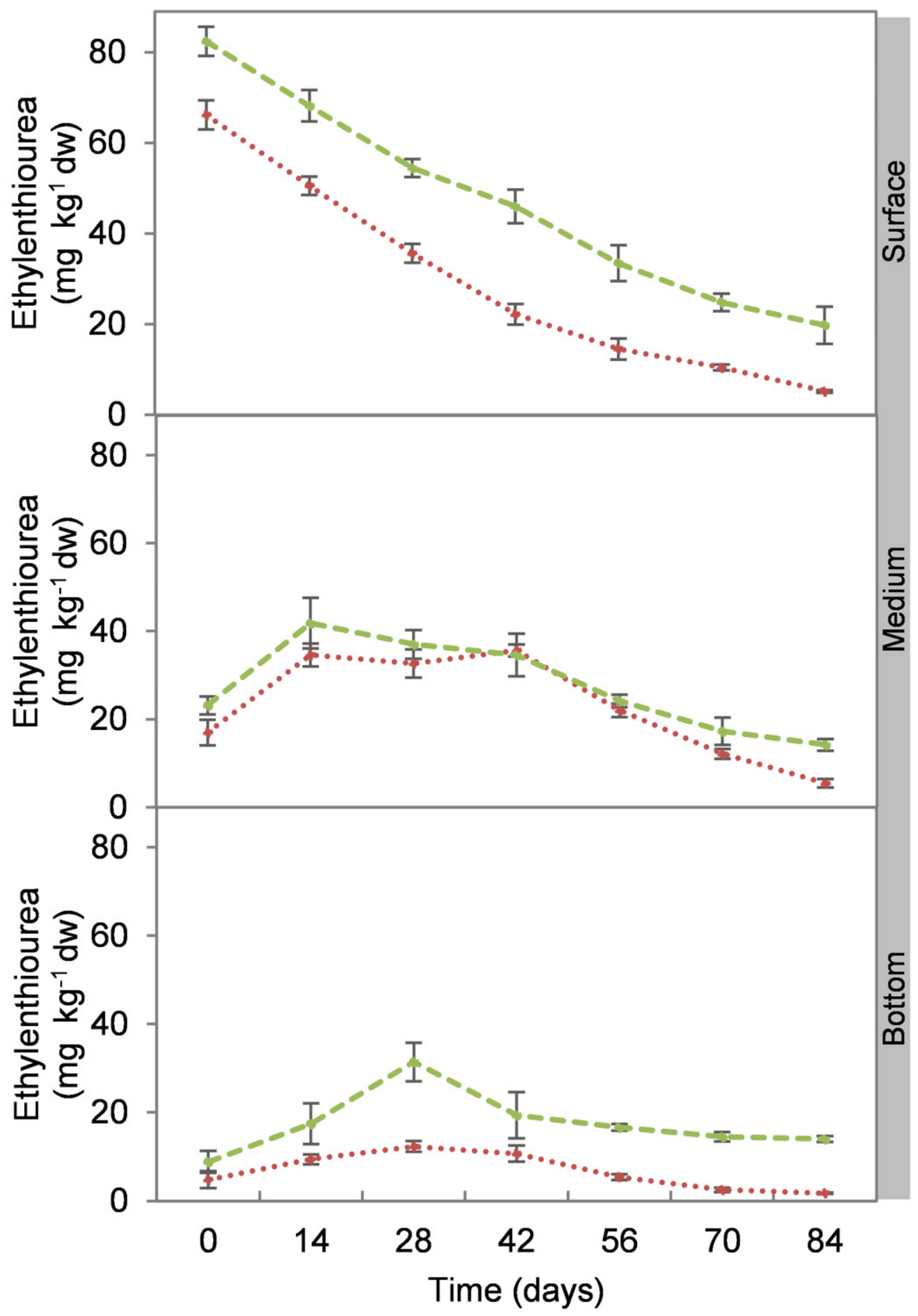


Figure 2

Kinetics of bacterial colonies at three depths in biobed polluted with Mancozeb $(1,000$ $\left.m g L^{-1}\right)$.

Error bars represent the standard deviation of three replications. 


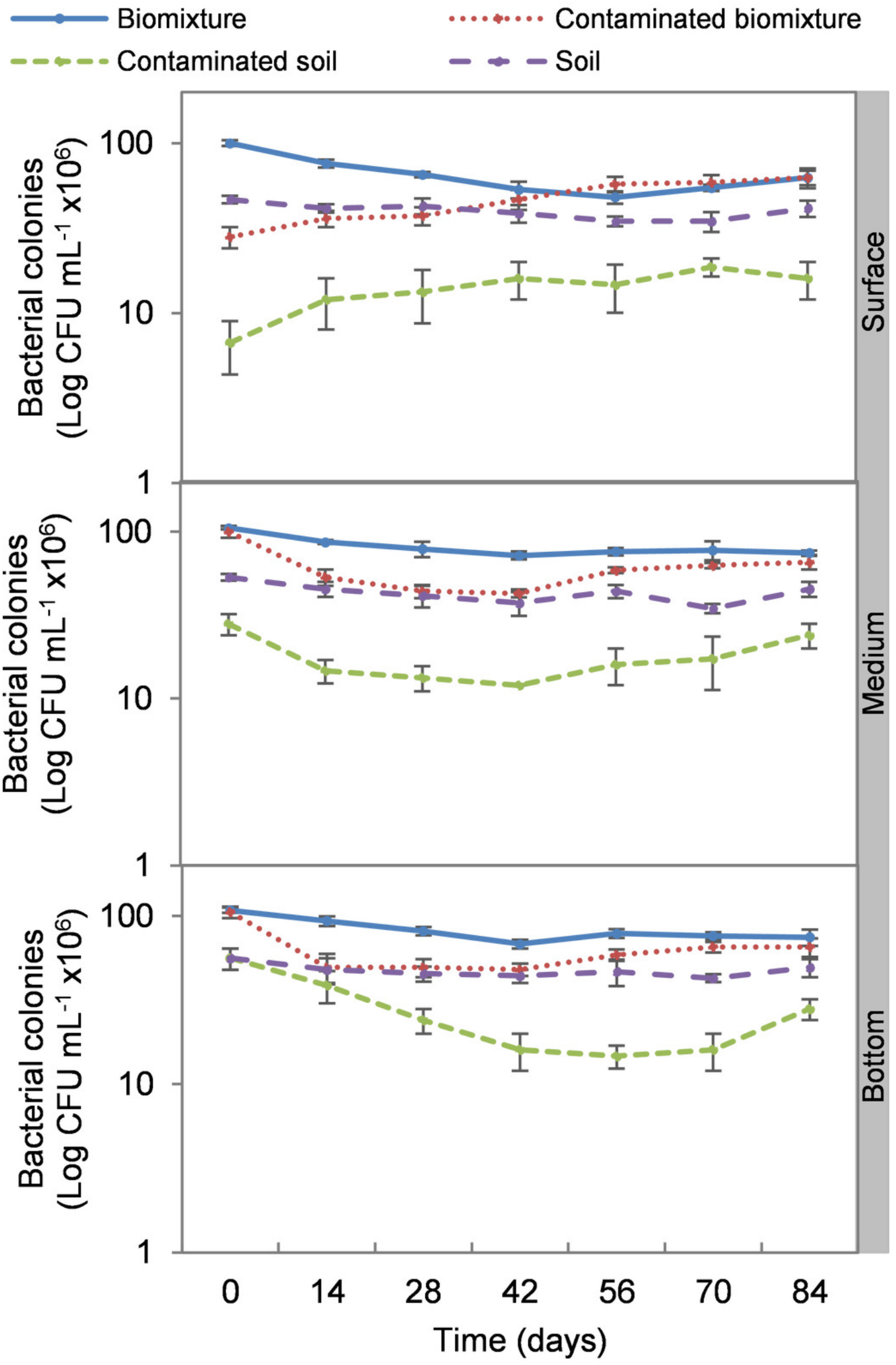


Figure 3

Kinetics of fungal colonies at three depths in biobed polluted with Mancozeb $(1,000 \mathrm{mg}$

$\left.L^{-1}\right)$.

Error bars represent the standard deviation of three replications. 


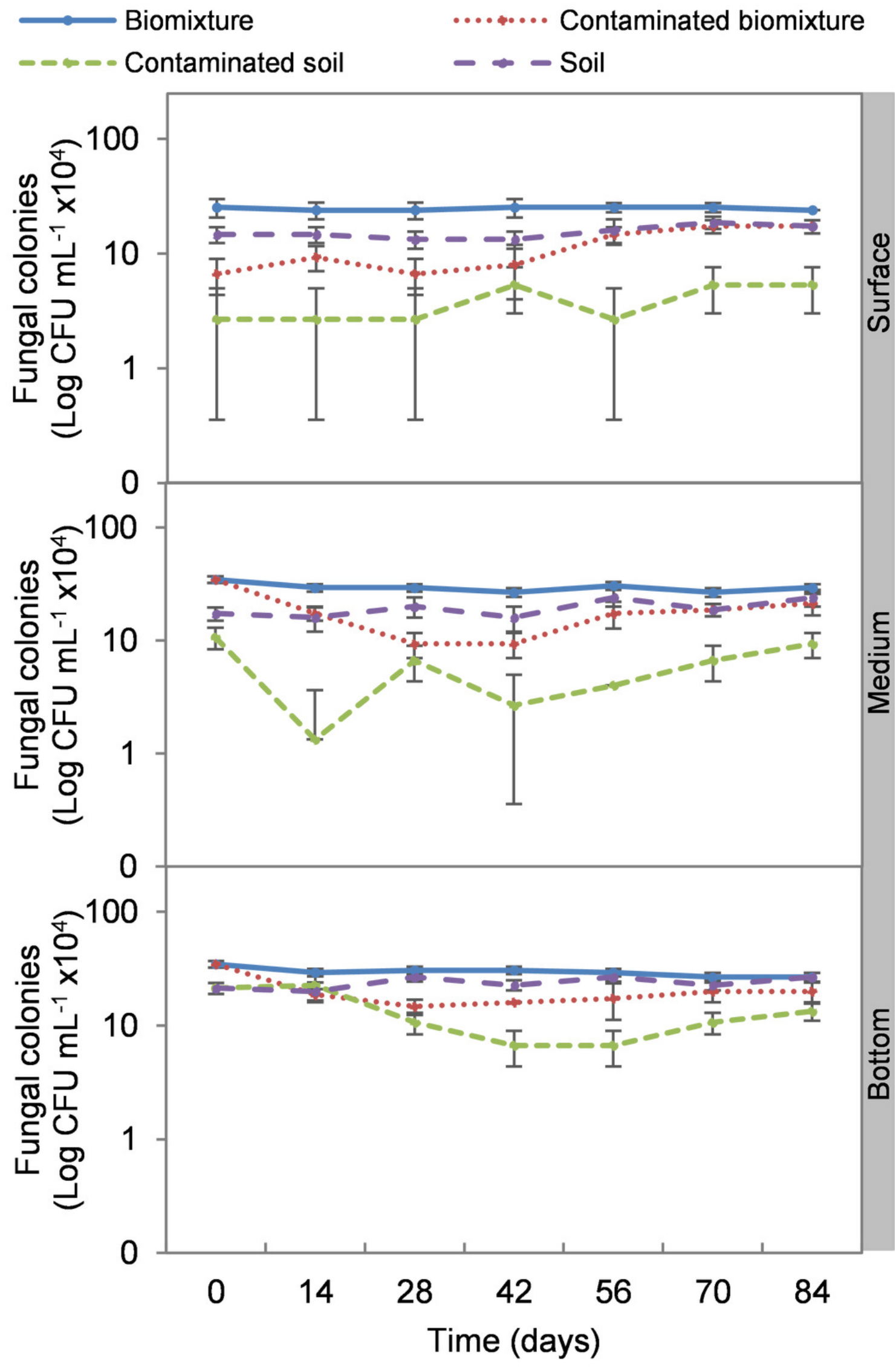


Figure 4

Kinetics of bacterial cells at three depths in biobed polluted with Mancozeb $(1,000 \mathrm{mg}$ $\left.\mathrm{L}^{-1}\right)$.

Error bars represent the standard deviation of three replications. 


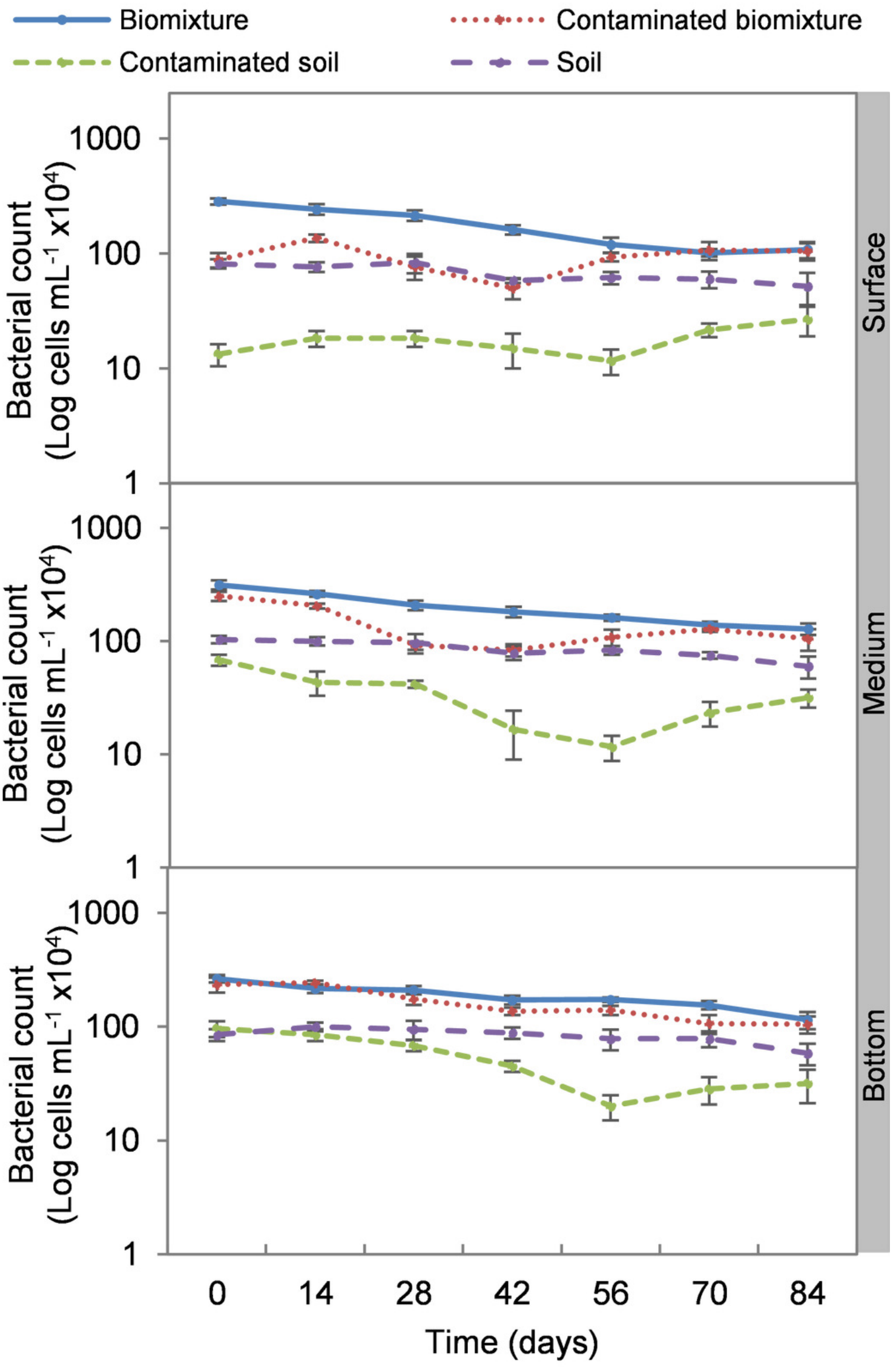




\section{Figure 5}

Kinetics of fungal cells at three depths in biobed polluted with Mancozeb $\left(1,000 \mathrm{mg} \mathrm{L}^{-1}\right)$.

Error bars represent the standard deviation of three replications. 


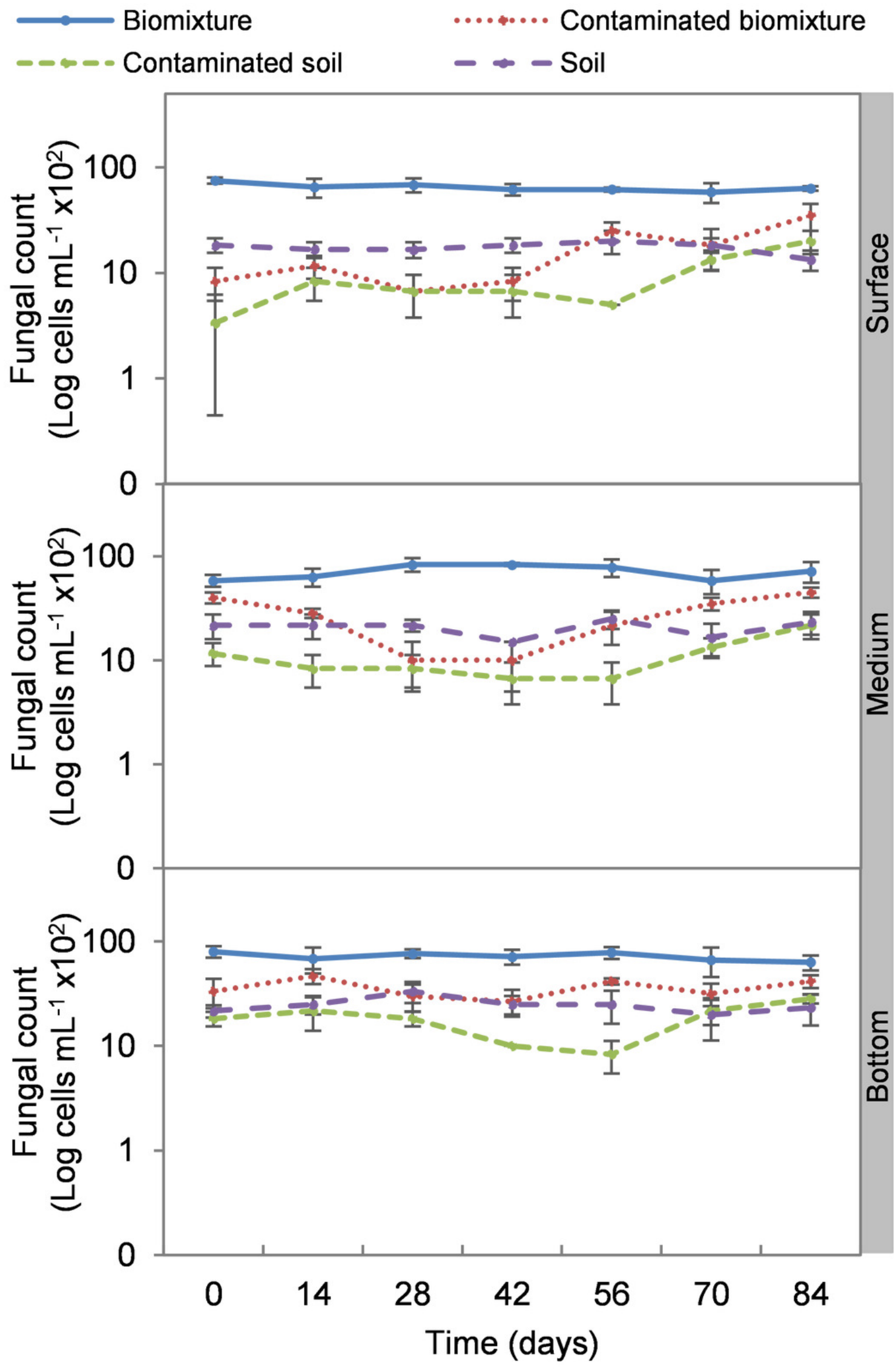




\section{Table $\mathbf{1}$ (on next page)}

Initial characterization of the materials used in the preparation of the biomixture. 


\begin{tabular}{lcccc}
\hline & Soil & Banana stem & Mulch & Biomixture \\
\hline & 54 clay & & & \\
Texture (\%) & 31 silt & - & - & - \\
& 15 sand & & & \\
Field capacity (\%) & 35.0 & - & - & 41.2 \\
Moisture (\%) & 45.6 & 65.2 & 12.5 & 55.3 \\
$\mathrm{pH}$ & 5.5 & 10.1 & 5.7 & 6.7 \\
Electrical conductivity $\left(\mathrm{dS} \mathrm{m}^{-1}\right)$ & 0.04 & 0.06 & 0.1 & 0.08 \\
Cation exchange capacity $\left(\mathrm{cmol}^{-1}(+) \mathrm{kg}^{-1}\right)$ & 58.2 & 28.2 & 12.3 & 86.2 \\
Organic matter content $(\%)$ & 6.5 & 33.2 & 17.2 & 24.4 \\
Carbon (\%) & 24 & 74 & 51 & 48 \\
Nitrogen (\%) & 0.25 & 0.87 & 0.98 & 1.85 \\
Ratio Carbon-nitrogen $(\mathrm{C} / \mathrm{N})$ & 96 & 85 & 1 & 25 \\
\hline
\end{tabular}

2 


\section{Table 2 (on next page)}

Comparison of initial and final values after 85 days of the microbial colony and cell counts in soil and biomixture polluted with ethylenethiourea.

*The letters in the columns indicate statistically significant differences between treatment ( $\alpha$ $=0.05)$, values not connected by the same letter are different. 
1

\begin{tabular}{|c|c|c|c|c|c|c|}
\hline Treatment & Level & $\begin{array}{c}\text { Ethylenethiourea } \\
\left(\mathrm{mg} \mathrm{L}^{-1}\right)\end{array}$ & $\begin{array}{l}\text { Bacterial colonies } \\
\left(\mathrm{CFU} \mathrm{mL}^{-1} \times 1^{6}\right)\end{array}$ & 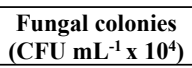 & $\begin{array}{l}\text { Bacterial count } \\
\left.\text { (cell } \mathrm{mL}^{-1} \times \mathbf{1 0}^{4}\right)\end{array}$ & $\begin{array}{c}\text { Fungal count } \\
\left(\text { cell } \mathrm{mL}^{-1} \times 1^{2}\right)\end{array}$ \\
\hline \multicolumn{7}{|l|}{ Experiment start (Day 1) } \\
\hline \multirow{4}{*}{ Biomixture } & Surface & $0.0 \pm 0.0 \mathrm{~h}$ & $100 \pm 4 a$ & $25 \pm 4 \mathrm{bcd}$ & $285 \pm 18 \mathrm{ab}$ & $75 \pm 5 \mathrm{ab}$ \\
\hline & Medium & $0.0 \pm 0.0 \mathrm{~h}$ & $105 \pm 2 \mathrm{a}$ & $34 \pm 2 \mathrm{a}$ & $315 \pm 30 \mathrm{a}$ & $58 \pm 7 \mathrm{bcd}$ \\
\hline & Bottom & $0.0 \pm 0.0 \mathrm{~h}$ & $108 \pm 4 \mathrm{a}$ & $34 \pm 2 \mathrm{a}$ & $265 \pm 20 \mathrm{ab}$ & $80 \pm 10 \mathrm{a}$ \\
\hline & Surface & $66.2 \pm 3.2 \mathrm{~b}$ & $28 \pm 4 \mathrm{fgh}$ & $6 \pm 2$ ghi & $88 \pm 12 \mathrm{cdef}$ & $8 \pm 2 \mathrm{jk}$ \\
\hline \multirow{3}{*}{ Contaminated biomixture } & Medium & $17.0 \pm 2.8 \mathrm{de}$ & $100 \pm 8 \mathrm{a}$ & $34 \pm 2 \mathrm{a}$ & $250 \pm 22 b$ & $40 \pm 5 \mathrm{defg}$ \\
\hline & Bottom & $4.8 \pm 1.9 \mathrm{fgh}$ & $105 \pm 8 \mathrm{a}$ & $34 \pm 2 \mathrm{a}$ & $235 \pm 35 b$ & $33 \pm 10$ efghi \\
\hline & Surface & $0.0 \pm 0.0 \mathrm{~h}$ & $46 \pm 2 \mathrm{de}$ & $14 \pm 2 \mathrm{efg}$ & $81 \pm 7$ cdefg & $18 \pm 2$ hijk \\
\hline \multirow[t]{3}{*}{ Soil } & Medium & $0.0 \pm 0.0 \mathrm{~h}$ & $53 \pm 2$ cde & $17 \pm 2$ def & $103 \pm 7$ cdef & $21 \pm 5$ fghi \\
\hline & Bottom & $0.0 \pm 0.0 \mathrm{~h}$ & $56 \pm 8$ cde & $21 \pm 2$ bcde & $85 \pm 10$ cdefg & $21 \pm 2$ fghijk \\
\hline & Surface & $82.4 \pm 3.2 \mathrm{a}$ & $6 \pm 2 \mathrm{i}$ & $2 \pm 2 \mathrm{i}$ & $13 \pm 2 \mathrm{i}$ & $3 \pm 2 \mathrm{k}$ \\
\hline \multirow[t]{2}{*}{ Contaminated soil } & Medium & $23.1 \pm 2.0 \mathrm{c}$ & $28 \pm 4 \mathrm{fgh}$ & $10 \pm 2$ fghi & $68 \pm 7$ defgh & $11 \pm 2 \mathrm{jk}$ \\
\hline & Bottom & $8.8 \pm 2.4 \mathrm{f}$ & $56 \pm 8$ cde & $21 \pm 2$ bcde & $96 \pm 15 \mathrm{cdef}$ & $18 \pm 2 \mathrm{hijk}$ \\
\hline \multicolumn{7}{|l|}{ Experiment end (Day 84) } \\
\hline \multirow{3}{*}{ Biomixture } & Surface & $0.0 \pm 0.0 \mathrm{~h}$ & $62 \pm 6 \mathrm{bcd}$ & $24 \pm 0 \mathrm{bcd}$ & $108 \pm 17 \mathrm{cde}$ & $63 \pm 2 a b c$ \\
\hline & Medium & $0.0 \pm 0.0 \mathrm{~h}$ & $74 \pm 2 b$ & $29 \pm 1 \mathrm{ab}$ & $128 \pm 15 \mathrm{c}$ & $71 \pm 16 \mathrm{ab}$ \\
\hline & Bottom & $0.0 \pm 0.0 \mathrm{~h}$ & $74 \pm 8 \mathrm{~b}$ & $26 \pm 2 \mathrm{abc}$ & $115 \pm 20 \mathrm{~cd}$ & $63 \pm 10 \mathrm{abc}$ \\
\hline \multirow{3}{*}{ Contaminated biomixture } & Surface & $5.1 \pm 0.3 \mathrm{fg}$ & $62 \pm 8 \mathrm{bcd}$ & $17 \pm 2$ def & $105 \pm 18 \mathrm{cdef}$ & $35 \pm 10$ efgh \\
\hline & Medium & $5.4 \pm 0.9 \mathrm{fg}$ & $65 \pm 6 b c$ & $21 \pm 4$ bcde & $105 \pm 22 \mathrm{cdef}$ & $45 \pm 5 \mathrm{cde}$ \\
\hline & Bottom & $1.8 \pm 0.1 \mathrm{gh}$ & $65 \pm 8 \mathrm{bc}$ & $20 \pm 4$ cde & $105 \pm 18 \mathrm{cdef}$ & $41 \pm 5 \mathrm{def}$ \\
\hline \multirow{3}{*}{ Soil } & Surface & $0.0 \pm 0.0 \mathrm{~h}$ & $41 \pm 4$ efg & $17 \pm 2$ def & $51 \pm 16$ fghi & $13 \pm 2 \mathrm{ijk}$ \\
\hline & Medium & $0.0 \pm 0.0 \mathrm{~h}$ & $45 \pm 4 \mathrm{def}$ & $24 \pm 4 \mathrm{bcd}$ & $60 \pm 13$ efghi & $23 \pm 5$ fghijk \\
\hline & Bottom & $0.0 \pm 0.0 \mathrm{~h}$ & $49 \pm 6 \mathrm{cde}$ & $26 \pm 2 a b c$ & $58 \pm 12$ efghi & $23 \pm 7$ fghijk \\
\hline \multirow{3}{*}{ Contaminated soil } & Surface & $19.7 \pm 4.1 \mathrm{~cd}$ & $16 \pm 4 \mathrm{hi}$ & $5 \pm 2 \mathrm{hi}$ & $26 \pm 7 \mathrm{hi}$ & $20 \pm 5$ ghijk \\
\hline & Medium & $14.2 \pm 1.3 \mathrm{e}$ & $24 \pm 4$ ghi & $9 \pm 2$ fghi & $31 \pm 5$ ghi & $21 \pm 5$ fghijk \\
\hline & Bottom & $14.0 \pm 0.6 \mathrm{e}$ & $28 \pm 4 \mathrm{fgh}$ & $13 \pm 2 \mathrm{efgh}$ & $31 \pm 10 \mathrm{ghi}$ & $28 \pm 2$ efghij \\
\hline
\end{tabular}

2 


\section{Table 3 (on next page)}

Correlation matrix between physicochemical and biological parameters in biomixtures and soils polluted with ethylenethiourea.

$\rho$ - Value with a negative sign indicates a negative correlation. Prob $>|\rho|$ indicates the probability that the correlation is significant. CEC cation exchange capacity, ETU ethylenethiourea, OM organic matter. 
1

\begin{tabular}{cccc}
\hline Variable x & Variable y & $\boldsymbol{\rho}$ de Spearman & Prob $>\boldsymbol{\rho}$ \\
\hline pH & Bacterial colonies & 0.77 & $<.0001$ \\
pH & Fungal colonies & 0.59 & $<.0001$ \\
pH & Bacterial cells & 0.59 & $<.0001$ \\
pH & Fungal cells & 0.61 & $<.0001$ \\
CEC & Bacterial colonies & -0.62 & $<.0001$ \\
CEC & Fungal colonies & -0.40 & $<.0001$ \\
CEC & Bacterial cells & -0.71 & $<.0001$ \\
CEC & Fungal cells & -0.24 & $<.0001$ \\
OM & Bacterial colonies & 0.66 & $<.0001$ \\
OM & Fungal colonies & 0.49 & $<.0001$ \\
OM & Bacterial cells & 0.76 & $<.0001$ \\
OM & Fungal cells & 0.28 & 0.001 \\
Moisture & Bacterial colonies & 0.62 & $<.0001$ \\
Moisture & Fungal colonies & 0.61 & $<.0001$ \\
Moisture & Bacterial cells & 0.55 & $<.0001$ \\
Moisture & Fungal cells & 0.46 & $<.0001$ \\
ETU & Bacterial colonies & -0.67 & $<.0001$ \\
ETU & Fungal colonies & -0.73 & $<.0001$ \\
ETU & Bacterial cells & -0.50 & $<.0001$ \\
ETU & Fungal cells & -0.77 & $<.0001$ \\
CEC & pH & -0.56 & $<.0001$ \\
ETU & pH & -0.58 & $<.0001$ \\
OM & pH & 0.57 & $<.0001$ \\
OM & CEC & -0.91 & $<.0001$ \\
CEC & Moisture & -0.26 & 0.003 \\
ETU & Moisture & -0.35 & $<.0001$ \\
OM & Moisture & 0.34 & $<.0001$ \\
Moisture & pH & 0.25 & 0.021 \\
ETU & CEC & 0.04 & 0.593 \\
ETU & OM & -0.10 & 0.244 \\
\hline & & &
\end{tabular}

